\title{
Neslihan Güler Selçuk: Acı Bir Kayıp Üzerine Yazmak
}

\section{Neslihan Güler Selçuk: Overwriting a Painful Loss}

\section{Bülent Yılmaz*}

\section{$\ddot{\boldsymbol{O}} \boldsymbol{z}$}

18 Nisan 2021 tarihinde hiç beklenmedik biçimde yitirdiğimiz Sevgili arkadaşımız ve meslektaşımız Neslihan Güler Selçuk'un ardından yazmak gerçekten çok zor. Zihinde anılar, duygular, düşünceler, hüzünler, fotoğraflar, sözcükler siralanlyor peş peşe. Insan ne yazacă̆ını, nasıl yazacă̆ını, daha doğrusu yazıp yazmaması gerektiğini kestiremiyor. Acıyı yazmak, acıyla yazmak kolay değil çünkü. Çok özleyeceğiz onu.

Anahtar Sözcükler: Neslihan Güler Selçuk; kütüphaneci; Türk kütüphaneciliği.

\begin{abstract}
It is really difficult to write after our dear friend and colleague Neslihan Güler Selçuk, whom we lost unexpectedly on April 18, 2021. In the mind, memories, emotions, thoughts, sorrows, photographs, words are lined up one after another. One cannot predict what to write, how to write, more precisely whether or not to write. It is not easy to write with pain, because it is not easy. We will miss her very much.
\end{abstract}

Keywords: Neslihan Güler Selçuk; librarian; Turkish librarianship.

Koronavirüs salgını döneminde her gün yeni acı haberlerle uyanıyoruz, irkiliyoruz, sarsılıyoruz. Yitirdiklerimize eklenenler oluyor. Birinin acısı azalmadan diğerininki doluyor yüreğimize. Hiçbirisine yakıştıramıyoruz ölümü, "çok erkendi, hiç olmadı." diyoruz. Kabullenemiyoruz çoğu zaman. Hele yakından biliyor, tanıyorsak yitirdiğimiz insanı; güzel bir ortak geçmişe sahipsek onunla, yazmak daha da güçleşiyor. Elimiz ve yüreğimiz varmıyor kaleme. "Yazsam bir türlü, yazmasam bir türlü." diye düşünüyor insan. Yazmak yüreği acıtıyor dostun ardından, yazmamak vicdan1.

Hacettepe Üniversitesi Kütüphanecilik Bölümü lisans döneminden arkadaşımdı Sevgili Neslihan. Aynı ilçede doğduğumuzu tanıştıktan sonra öğrenmiştik. Yemyeşil gözleri, gamzeleri, soyadına yakışır hep gülen yüzü ile en güzel arkadaşlarımızdandı o. Genel olarak neşeliydi, espriyi severdi, hoşgörülüydü, sevecendi, sevgi doluydu; ciddi olunacağı zaman ciddi de oluverirdi, sınırları vardı. Güvenilirdi, yakındı, paylaşımcıydı, dosttu, sonsuz sabırla dinlerdi. Arkadaş gibi arkadaştı. Beytepe yurtlarının kantinlerinde yaptığımız şakalarla, esprilerle, takılmalarla saatlerce güldügümüzü anımsarım. Becerikli ve evcimendi. Bize güzel kurabiyeler, poğaçalar yapardı. Geçen yıl sosyal medya hesabında "erik turşusu" tarifini ve fotoğraf paylaşımını görünce o günlere gidivermiştim. Bir de Ankara-Manisa arası 12-13 saat

\footnotetext{
* Hacettepe Üniversitesi Bilgi ve Belge Yönetim Bölümü, Ankara, Türkiye. E-posta: byilmaz963@gmail.com Hacettepe University Department of Information Management, Ankara, Turkey. E-mail: byilmaz963gmail.com
}

Geliş Tarihi - Received: 09.05.202

Kabul Tarihi - Accepted: 16.05.2021

Yayımlanma Tarihi - Published: 30.06.2021 
süren o berbat ama aynı zamanda muhteşem İzmir Mavi Tren yolculuklarımızı anımsıyorum; o ne keyifti, ne muhabbet, ne kahkahalardı!

Bölümünü, mesleğini severdi. Ders çalışırdık hep beraber. Sınıfların bulunduğu koridorda sınav öncesi arkadaşlarıyla hararetli bilgi tekrarlarına tanık olurdum çoğu zaman. Başarılı bir öğrenciydi de.

Çağdaş düşünceli, cumhuriyet değerlerine duyarlı, aydın ve Atatürk sevgisi güçlü bir arkadaşımızdı. Doğa ve hayvan dostuydu.

Mezun olduktan sonra her birimiz hayat derdine düşüp, bir taraflara savrulunca çok görüşemez olduk. Yine de aynı şehirde, Ankara'daydık. Mesleki toplantılarda karşılaşırdık. Ne kadar görüşemez de olsak, yüz yüze geldiğimiz anda kaldığımız yerden devam ederdik konuşmaya, gülmeye, anlatmaya. Yetmezdi tabi, yeterince görüşemediğimizi duyumsardık, üzülürdük. "Olsun,” derdik, "Gönüllerimiz bir!” Arada çalıştığı kütüphaneyi ziyaret ederdim. Sosyal medyadan görüşür, selamlaşır olduk son zamanlarda.

Sonra bir gün, 18 Nisan 2021 günü sosyal medyada o güzelim öğrenci yüzünü vesikalık fotoğrafta gördüğüm anda içim cız etti! Altta yazan yazıyı tahmin etmek, okumak istemedim. "Yok, olamaz, başka bir nedenledir." dedim. "Sevenlerine başsağlığı dileriz!" diye bitiyordu ne yazık ki yazı. Ne düşüneceğimi, ne diyeceğimi bilemedim. "Hiç yakışmad1, çok erken, hiç olmad1, neden, nasıl yani, doğru mu bu?” türünden bir sürü soru, yargı, duygu, düşünce karıştı birbirine. Ama gerçek şuydu: Neslihan Güler Selçuk'u gencecik yaşta, üç günde korona belasıyla kaybetmiştik.

Düşündükçe aklımda en çok uçuşan ve durmadan yinelediğim sözcükler hâlâ "olamaz ve inanılmaz!"

Oldu ama birakt1, gitti.

Hiç yakışmadı be Arkadaşım!

Özleyeceğiz seni, hem de çok özleyeceğiz!

Anılarımızda yaşatacağız; hep sevgiyle anacağız, gülen yüzünle, yemyeşil gözlerin ve güzel yüreğinle anımsayacağız seni.

Hoşçakal Sevgili Neslihan!

Işıklar içinde uyu Sevgili Arkadaşım!

9 May1s 2021, Ankara 